\title{
FEM RESEARCH OF INTERNAL STRESSES EVOLUTION IN THE PRESTRESSING STRAND PRODUCTION
}

\author{
${ }^{1}$ Alexey KORHUNOV, ${ }^{1}$ Ekaterina MEDVEDEVA, ${ }^{1}$ Polina IVEKEEVA, ${ }^{1}$ Dmitrii KONSTANTIOV \\ ${ }^{1}$ Nosov Magnitogorsk State Technical University, Magnitogorsk, Russian Federation, \\ international@magtu.ru, fekla med@mail.ru, fufest01@mail.ru, const dimon@mail.ru
}

https://doi.org/10.37904/metal.2020.3489

\begin{abstract}
The article presents the finite-element modeling results of stranding, reduction, straightening and mechanicalthermal treatment (MTT) of prestressing strand (PSC strand). Computer models took into account the distribution of residual stresses formed at the preliminary stage of wire drawing. During the simulation, the effect of MTT on the internal stresses of the wires was studied: residual stresses after the drawing process and additional stresses after the stranding. All studied methods demonstrated a positive effect not only from the point of eliminating internal stresses, but also from the point of view of their favorable redistribution. The reduction of PSC strand in a monolith tool with strain degree 1-3\% allows to minimize tensile stresses on the surface of the wires and save compressive stresses in the center of the wires. The straightening by a group of 5 rolls made it possible to reduce the tension of outer wires twice. The MTT application, combining the effects of various physical nature, made it possible to control over a wide range the redistribution of residual stresses in the wires after high strain degrees and the additional stresses created during the stranding, which affect the preservation of the geometric parameters of the PSC strand. The study showed that to eliminate longitudinal residual stresses, the magnitude of the tension in the MTT is the most important parameter. Therefore, with a minimum value of tension, the residual stresses are not redistributed either in the central or in the surface layers, regardless of the temperature of the MTT. However, with tension above $70 \mathrm{kN}$ and a temperature of $380-400^{\circ} \mathrm{C}$, the residual stresses in the center and on the surface of the wires are balanced or almost completely eliminated.
\end{abstract}

Keywords: Prestressing strand, mechanical-thermal treatment, finite-element modeling, internal stresses, stranding, straightening

\section{INTRODUCTION}

Most metalware products are multicomponent (ropes, nets, etc.) or have a complex geometric shape (bolts, nuts, etc.). Since the use of hardware products is often associated with areas of responsible construction or design (and, therefore, with complex loading schemes), there is an urgent need to take into account the contribution of each technological operation to the exploitation and technological properties of the final product.

This is especially clearly demonstrated by the example of PSC strand production, the application of which can significantly reduce cost of prestressed concrete products and structures while improving quality [1]:

- $\quad$ The heat treatment operation gives the wire the necessary initial microstructure,

- Multistage drawing determines the geometry, stress-strain state (SSS) and steel microstructure,

- $\quad$ Stranding, straightening and mechanical-thermal treatment (MTT) change the SSS of each individual wire and the entire PSC strand.

Specific features of the production and application of PSC strand are the subject of many theoretical and experimental studies [2-11]. The main property-forming parameters in this case are the steel microstructure and internal stresses, which determine the final level of strength and relaxation resistance. If the microstructure formation is relatively simple using experimental and laboratory studies [13], then the prediction of residual stresses level in multioperational technologies is optimally performed using computer simulation methods. 
The aim of this work is a computer study of the gradual formation of internal stresses in the PSC strand production and the influence of various MTT modes on their distribution.

\section{MATERIALS AND METHODS}

Production process of a PSC strand $1 \times 7(1+6)$ with a diameter $12.5 \mathrm{~mm}$ and strength class $1770 \mathrm{MPa}$ from pearlitic steel was selected as the research object. The chemical composition and mechanical properties of the wire are presented in Table 1. The production process included the following technological operations: stabilization, surface preparation for drawing, multistage cold drawing, stranding, straightening, mechanicalthermal treatment.

Table 1 The chemical composition and mechanical properties of the wire for PSC strand

\begin{tabular}{|c|c|c|c|c|c|c|}
\hline $\mathbf{C}$ & $\mathbf{M n}$ & $\mathbf{S i}$ & $\mathbf{C r}$ & $\mathbf{N i}$ & $\mathbf{V}$ & Tensile strength after drawing $\boldsymbol{\sigma}_{\mathbf{B}}(\mathbf{M P a})$ \\
\hline 0,80 & 0,48 & 0,28 & 0,05 & 0,02 & 0,11 & 2200 \\
\hline
\end{tabular}

Since the wire drawing technology involves high strain degrees $\sim 88-90 \%$, this process will inevitably lead to the residual stresses generation that directly affect both the mechanical and exploitation properties of the future PSC strand, and the stability of the process of stranding [13-20]. For this reason, the analysis of the technological process should be based on the assessment of the absolute values and distribution of residual stresses that make the most significant contribution to the stress-strain state of PSC strand. In this case, the stress state of PSC strand is further complicated by the addition of lay stresses at the stage of forming the strands on the rope machine.

The wire drawing process, preceding the operations of straightening, stranding and MTT, was described and investigated on the basis of an industrial experiment and multiscale modeling in paper [21]. The traditionally used MTT temperature values are the range of $360-400{ }^{\circ} \mathrm{C}$. Taking into account the traditionally used values of tension, the level of mechanical properties after the drawing process, the geometric parameters of the PSC strand and the technological capabilities of the existing equipment, the tension varied in the range $(58 \div 82)$ $\mathrm{kN}$. The rope lay was $200 \mathrm{~mm}$.

For the research, three models were created:

1) Model of stranding and reduction of PSC strand in monolith tool: the strand were twisted till the rope lay parameter; then it is crimped in a monolithic tool with strain degrees $1 \%, 2 \%$ and $3 \%$.

2) Model of straightening: the strand were twisted till the rope lay parameter, and then passed through a group of five horizontally arranged rollers with a diameter $100 \mathrm{~mm}$ and a depth $5 \mathrm{~mm}$.

3) Model of MTT: the strand were twisted till the rope lay parameter; then it is heated to the indicated temperature from the range; tension is applied to its end; finaly tension and temperature are removed at the same time.

In all models in the initial state, the distribution of residual stresses was used after the drawing process investigated and verified in [21].

\section{RESULTS}

\subsection{Model of PSC strand reduction in monolith tool}

The use of monolith tool (similar construction as in wire drawing) in strand machines can help improve the stress-strain state, create favorable contact conditions, increase the size precision, while also save interwire clearance. However, an important point is the assignment of the correct reduction value in the tools, because at the initial stages of reduction (in the zone of elastic strain) the formation of inhomogenious stress state with a large proportion of tensile stresses is observed, which leads to reduction of plastic properties. 
The traditionally used reduction range is $1-3 \%$. Increase of reduction degree up to $4 \%$ or more leads to unfavorable increase in the energy parameters of the industrial process and deterioration of the mechanical properties. To account for the residual stresses, the cross-sections of the wires were divided into sections with the corresponding values of the axial residual stresses (Figures 1 and 2).

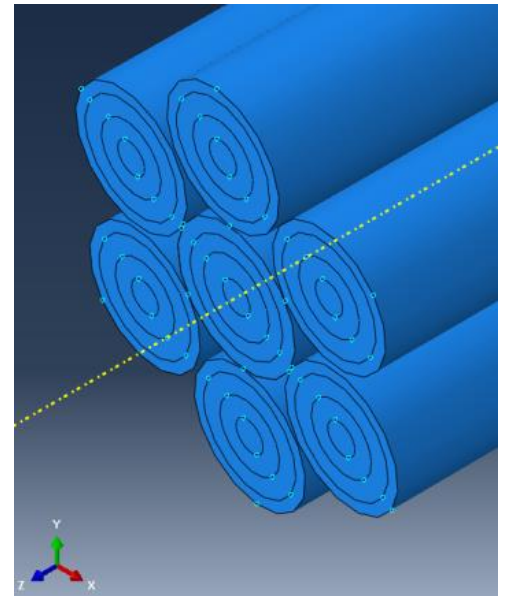

Figure 1 Wires cross section before stranding simulation

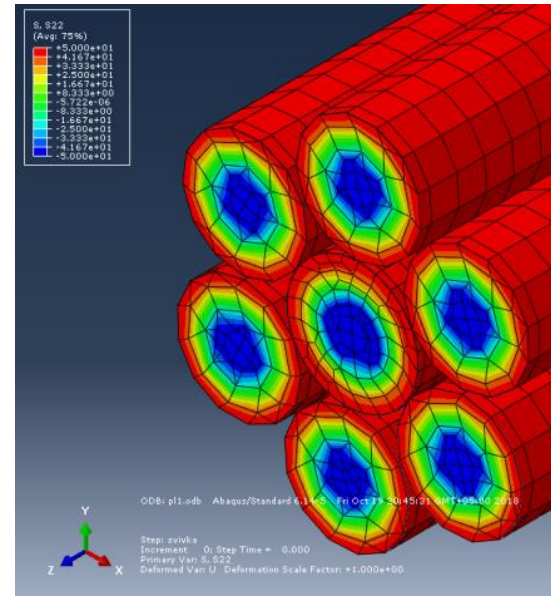

Figure 2 Initial distribution of longitudinal residual stresses

The Mises stress distribution in all three reduction modes (Figure 3) was uniform in the range from 300 to 600 $\mathrm{MPa}$. However, after the stranding the stress state was extremely inhomodenious with a significant difference in the stresses level on the surface and the center of the outer wires.

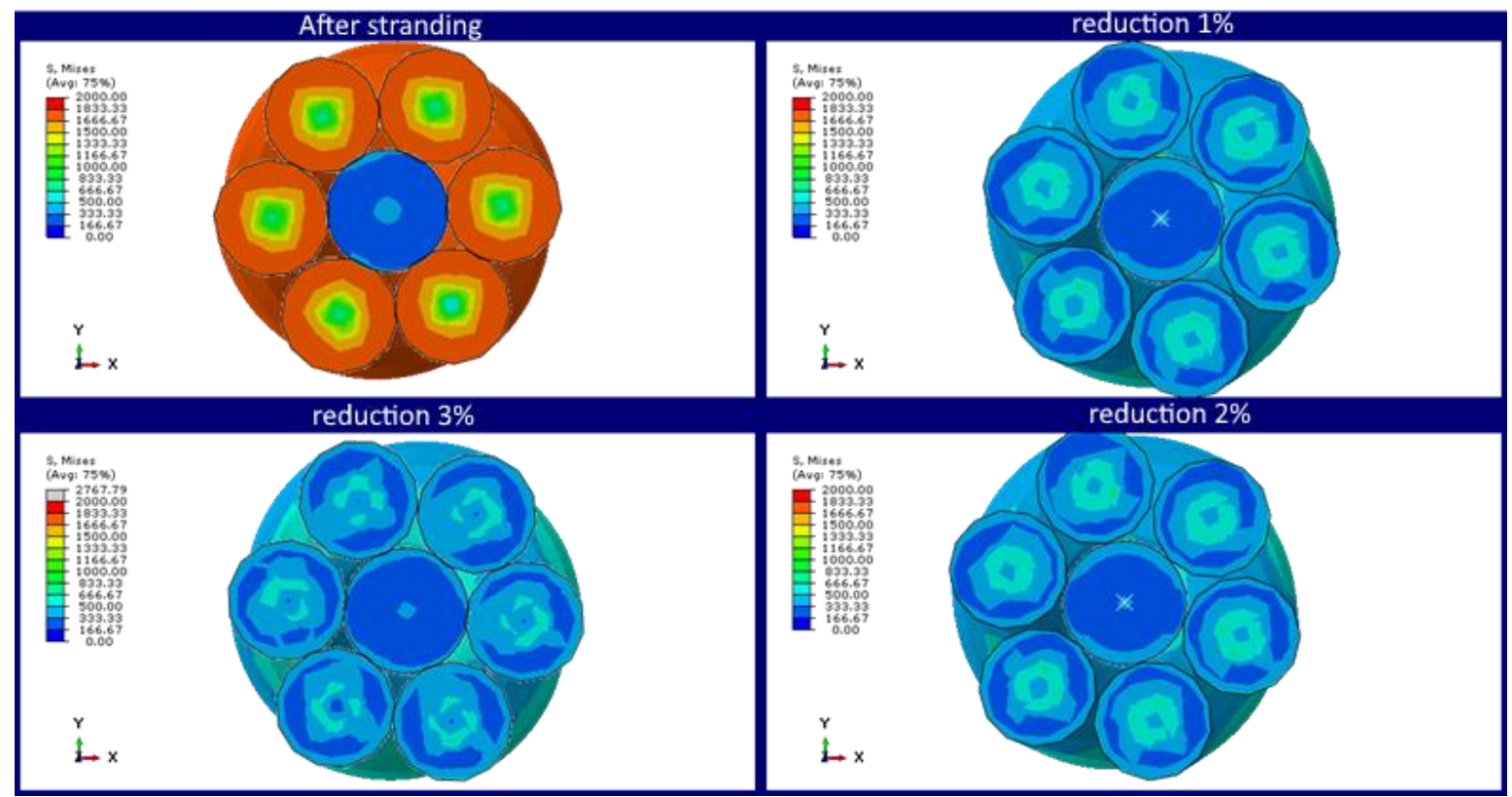

Figure 3 Mises stress distribution

The distribution of radial strains under 2-3\% reduction conditions differ slightly, but are most favorable relative to $1 \%$ reduction. Outer wires under these conditions have a favorable effect on the mechanical properties due to symmetrical localization of compression strains on the surface.

The $3 \%$ reduction creates the most favorable distribution of longitudinal stresses (Figure 4) with a minimized proportion of tensile stresses on the surface and maximum stored compressive stresses in the center of the wires. 


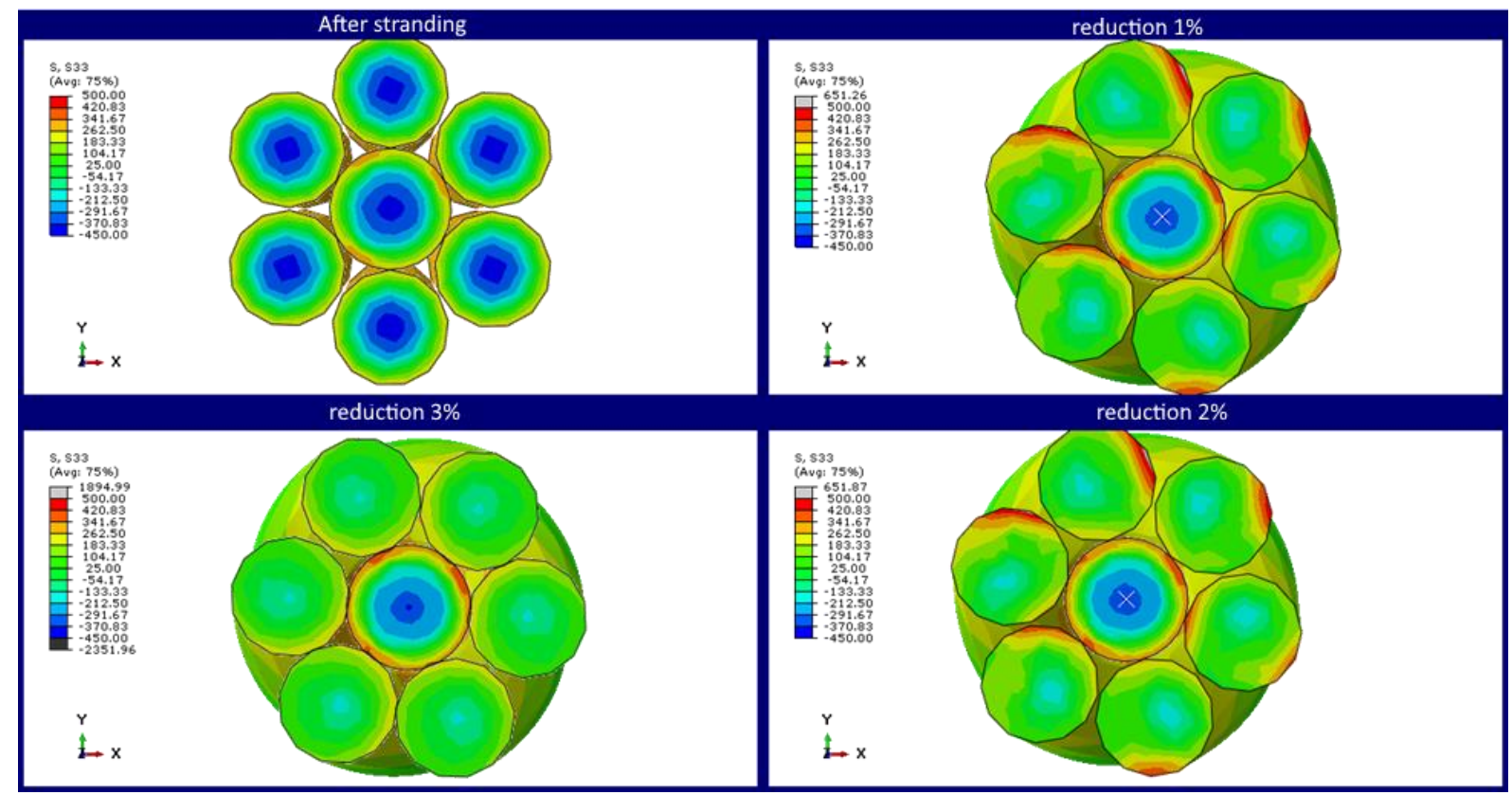

Figure 4 Distribution of longitudinal stresses

Thus, the most favorable stress-strain state is formed during reduction of at least $2 \%$.

\subsection{Straightening model}

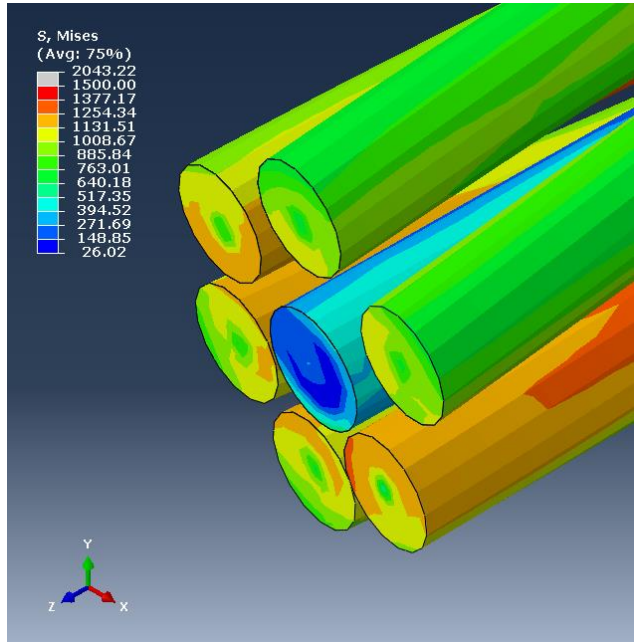

Figure 5 Mises stresses in the cross section of PSC strand

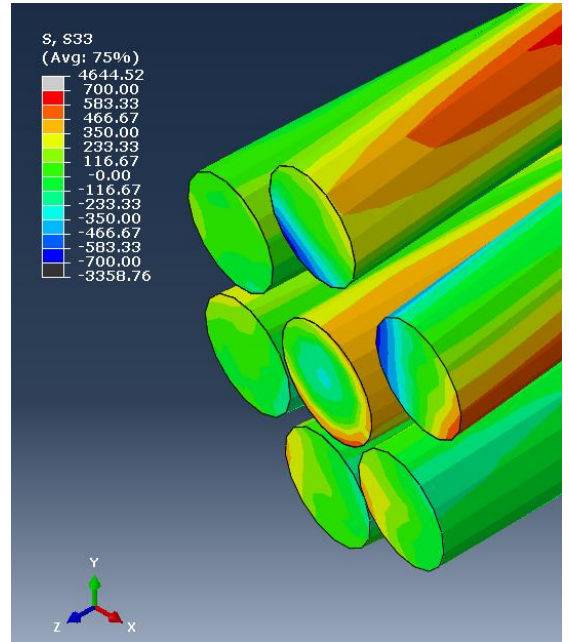

Figure 6 Longitudinal stresses in the cross section of PSC strand

Comparison of the distributions of the Mises stresses (Figure 5) and longitudinal stresses (Figure 6) showed that the straightening with depth up to $5 \mathrm{~mm}$ for a $12.5 \mathrm{~mm}$ rope in one group of rolls significantly changes the stress state (mainly its outer wires). The longitudinal stresses of the outer wires are reduced by 1.7-2 times, and in some wires they even reach near zero values. Mises stresses were reduced in all outer wires by 1.5-2 times, which favorably reduces the untwisting of the rope. However, a further increase in the depth can adversely affect the preservation of the strand geometry and lead to an increase in pulling force. Moreover, higher depth will inevitably lead to an increase in the size of the contact arc, what will negatively affect the wear of the rolls material. Therefore, installation of several alternating groups of straightening rolls (horizontal and vertical) will be rational decision. 


\subsection{MTT model}

At a minimum temperature of $360^{\circ} \mathrm{C}$ or at a minimum tension of $58 \mathrm{kN}, \mathrm{PSC}$ strand has a high tendency to geometry disruption. However, starting with a tension of $70 \mathrm{kN}$ and a temperature above $380^{\circ} \mathrm{C}$, the MTT process almost completely eliminates the lay stresses that tend to untwist the strand.

The distributions of the longitudinal residual stresses in the central wire after the MTT process are shown in Figure 7. To eliminate longitudinal residual stresses, the most important parameter is the tension value. Therefore, with a minimum value of tension, the residual stresses are practically not redistributed either in the central layers or in the surface layers, regardless of the temperature of the MTT process. At the same time, with tension of $70 \mathrm{kN}$ at temperatures of $360^{\circ} \mathrm{C}$ and $380^{\circ} \mathrm{C}$, a certain "boundary" state of the central wire is created, upon reaching which the residual stresses begin to be intensively redistributed. The most effective from the standpoint of eliminating residual stresses after drawing are tension $82 \mathrm{kN}$ at any of the studied temperatures and tension $70 \mathrm{kN}$ at a temperature of $400^{\circ} \mathrm{C}$. Under these conditions, the residual stresses in the center and on the surface of the wire are balanced or almost completely eliminated.

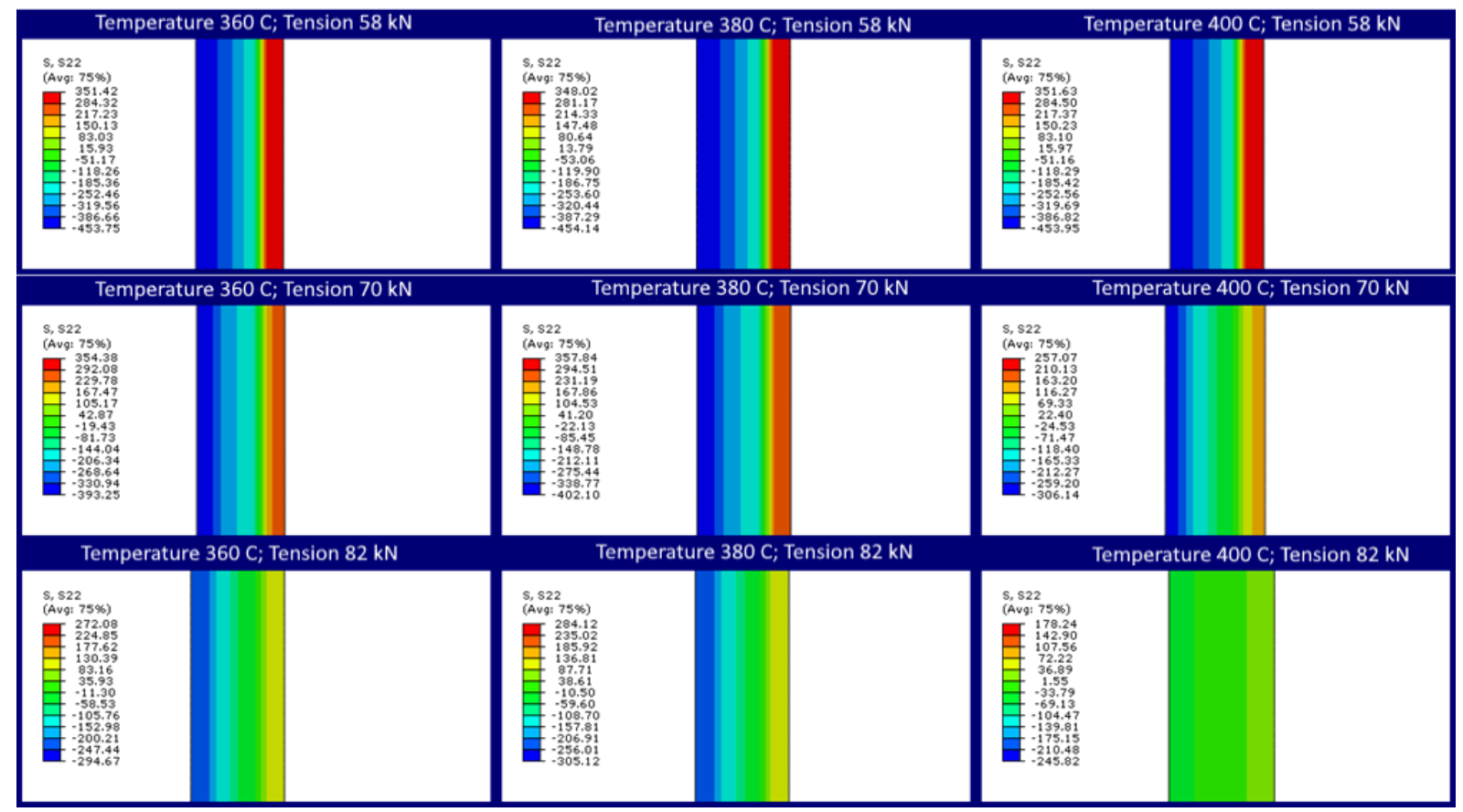

Figure 7 Longitudinal residual stresses in the central wire after the MTT process

\section{CONCLUSION}

The absolute values of residual stresses and their distribution in the wire for the production of $1 \times 7(1+6)$ PSC strand have a significant impact on the operational characteristics of the finished product. The application of the MTT allows a wide range to control the redistribution of residual stresses after high strain degrees by drawing and internal stresses that affect the preservation of the geometric parameters of the rope. During the drawing process, compressive residual stresses of 1100-1200 MPa are generated in the central layers of the wire. Moreover, on the wire surface, the residual stresses are tensile and equal to $450-500 \mathrm{MPa}$. The combination of tension $82 \mathrm{kN}$ or $70 \mathrm{kN}$ with a temperature range of $360-380{ }^{\circ} \mathrm{C}$ allows to achieve a twofold reduction in residual stresses in both the central and surface layers of the wire. When the temperature rises to $400{ }^{\circ} \mathrm{C}$ while maintaining the level of tension, it becomes possible to completely eliminate residual stresses. Reducing the tension does not lead to any changes in the residual stresses distribution. Stresses after stranding can be completely eliminated exclusively with a tension of $82 \mathrm{kN}$ or $70 \mathrm{kN}$ in the temperature range of $380-400{ }^{\circ} \mathrm{C}$. In other cases, the PSC strand geometry does not meet the standard. 


\section{ACKNOWLEDGEMENTS}

\section{The study was carried out within the framework of the implementation of the Resolution of the Government of the Russian Federation of April 9, 2010 No. 220 (Contract No. 075-15-2019-869 from May 12, 2019)}

\section{REFERENCES}

[1] MADATYAN, S.A. Sovremennyj uroven' trebovanij k napryagaemoj armature. Beton i zhelezobeton. 2005, no 1, pp. 810.

[2] EGOROV, V.D., VORONINA, V.S. Tekhnologiya proizvodstva armaturnyh kanatov v stabilizirovannom ispolnenii. Steel. 1983, no 3, pp. 65-66.

[3] COSTELLO, G.A. Theory of wire rope. Second edition. New York: Springer, 1997.

[4] FEYRER, K. Wire ropes: tension, endurance, reliability. Berlin-Heidelberg - New York: Springer, 2007.

[5] JACINTO L., PIPA M., SANTOS L. O. Probabilistic models for mechanical properties of prestressing strands. Construction and Building Materials. 2012, vol. 36, pp. 84-89.

[6] ONUR Y A. Experimental and theoretical investigation of prestressing steel strand subjected to tensile load. International Journal of Mechanical Sciences. 2016, vol. 118, pp. 91-100.

[7] OBAYDULLAH, M., JUMAAT M. Z. Prestressing of NSM steel strands to enhance the structural performance of prestressed concrete beams. Construction and Building Materials. 2016, vol. 129, pp. 289-301.

[8] MIHAJLOV, K.V. Zadachi otechestvennoj stroitel'noj nauki v oblasti armatury i predvaritel'no napryazhennyh zhelezobetonnyh konstrukcij. Beton i zhelezobeton. 2004, no 2, pp. 3-5.

[9] CHUKIN, M.V., GUN, G.S., KORCHUNOV, A.G., POLYAKOVA, M.A. Perspektivy proizvodstva vysokoprochnoj stal'noj armatury iz vysokouglerodistyh marok stali. Chernye metally. 2012, no 12, pp. 8-16.

[10] CHABBI L. Modelirovanie mikrostruktury i svojstv pri prokatke provoloki i prutkov. Chernye metally. 2017, no 9, pp. 5762.

[11] KORChUnOV, A. G., GUN, G. S., SHIRYAEV, O. P., PIVOVAROVA, K. G. Study of structural trans-formation of hotrolled carbon billets for highstrength ropes for responsible applications via the method of thermal analysis. CIS Iron and Steel Review. 2017, vol. 13, pp. 38-40.

[12] KORCHUNOV, A. G., POLYAKOVA, M. A., KONSTANTINOV, D. V., DABALÁ, M. Mechanical properties of prestressing strands and how they tend to change under thermo-mechanical treatment. CIS Iron and Steel Review. 2019, vol. 18, pp. 14-19.

[13] CABALLERO, L., ATIENZA, J. M., ELICES, M. Thermo-mechanical treatment effects on stress relaxation and hydrogen embrittlement of cold-drawn eutectoid steels. Metals and Materials International. 2011, vol. 17, no. 6, pp. 899-910.

[14] ATIENZA, J. M., ELICES, M., RUIZ-HERVIAS, J., CABALLERO, L., VALIENTE, A. Residual stresses and durability in cold drawn eutectoid steel wires. Metals and Materials International. 2007, vol. 13, no. 2, pp. 139-143.

[15] ATIENZA, J. M., ELICES, M. Influence of residual stresses in the stress relaxation of cold drawn wires. Materials and Structures / Materiaux et Constructions. 2004, vol. 37, pp. 301-304.

[16] ELICES M. Influence of residual stresses in the performance of cold-drawn pearlitic wires. Journal of materials science. 2004, vol. 39, pp. $3889-3899$.

[17] ATIENZA, J.M., RUIZ-HERVIAS, J., ELICES, M. The role of residual stresses in the performance and durability of prestressing steel wires. Experimental Mechanics. 2012, no. 52, pp. 881-893.

[18] ATIENZA, J.M., RUIZ-HERVIAS, J., MARTINEZ-PEREZ, M.L., MOMPEAN, F.J., GARCIA-HERNANDEZ, M., ELICES, M. Residual stresses in cold drawn pearlitic rods. Scripta Materialia. 2005, no. 52, no. 12, pp. 1223-1228.

[19] MARTINEZ-PEREZ, M.L., MOMPEAN, F.J., RUIZ-HERVIAS, J., BORLADO, C.R., ATIENZA, J.M., GARCIAHERNANDEZ, M., ELICES, M., GIL-SEVILLANO, J., RU LIN PENG, BUSLAPS. T. Residual stress profiling in the ferrite and cementite phases of cold-drawn steel rods by synchrotron X-ray and neutron diffraction. Acta Materialia. 2004, vol. 52, no. 18 , pp. 5303-5313.

[20] ZHENG WENZHONG, HU QIONG, ZHANG HAOYU. Experimental research on the mechanical property of prestressing steel wire during and after heating. Frontiers of Architecture and Civil Engineering in China. 2007, vo. 1, no. 2, pp. 247254.

[21] KONStANTINOV, D. V., KORChUNOV, A. G., ZAITSEVA, M. V., SHIRYAEV, O. P., EMALEEVA, D. G. Macro- and micromechanics of pearlitic-steel deformation in multistage wire production. Steel in Translation. 2018, vol. 48, pp. 458462. 